\title{
IMPLEMENTASI KEPEMIMPINAN TRANSFORMASIONAL KEPALA SEKOLAH DI SMA NEGERI 1 BARRU KABUPATEN BARRU
}

\author{
MUSDALIFAH, ARIFUDDIN SIRA, MARJUNI \\ Pascasarjana UIN Alauddin Makassar \\ Email: musdalifahmpi@gmail.com, arifuddinsiraj@gmail.com, h.marjuni@yahoo.com
}

(Article History)

Received September 01, 2020; Revised November 07, 2020; Accepted November 19, 2020

\begin{abstract}
:
This study aims to: Describe the implementation of idealized influence of headmaster in SMA Negeri 1 Barru, Barru Regency. This type of research is a qualitative descriptive study. With a phenomological approach. Data were collected through observation, interviews and documentation. Data were analyzed using data reduction methods, data presentation, drawing conclusions and verification. Testing the validity of the data through the credibility test, namely by using triangulation techniques (source, technique, and time) and member check. The results of this study indicate that the implementation of idealized influence of headmaster in SMA Negeri 1 Barru, Barru Regency, namely the involvement of teachers and staff in the field of meeting administration, giving ideas / opinions, forming a team of vision and mission formulation although not optimal teacher self-development because of the large number of teachers, optimal steps. Quality improvement through participatory and policy dissemination and the formation of activity implementers.
\end{abstract}

Keywords: Leadership Implementation, Trasformational, Headmaster

\section{PENDAHULUAN}

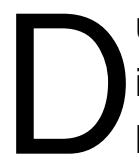

unia pendidikan saat ini berkembang begitu pesat dari masa ke masa. Saat ini, banyak bermunculan lembaga pendidikan sehingga persaingan yang ketat tidak dapat dihindarkan diantara lembaga pendidikan. Pendidikan memegang peranan penting dalam membuat suatu negara menjadi negara maju sehingga dapat bersaing dengan lembaga pendidikan di negara-negara lain. Pendidikan juga menjadi faktor utama agar dapat meningkatkan kehidupan masyarakat yang pada akhirnya akan menghasilkan keluaran yang berkualitas. Maka demikian diperlukan upaya dalam meningkatkan kualitas suatu sekolah agar bisa diatur, ditata serta diberdayakan. Pengelolaan sekolah tersebut dipimpin oleh seseorang kepala sekolah yang mempunyai wewenang dalam menerapkan gaya kepemimpinan tertentu untuk dapat mewujudkan tujuan dari sekolah. Dalam menjalankan tugasnya, Kepala sekolah akan berusaha untuk membuat kebijakankebijakan yang dianggap tepat untuk dapat mencapai tujuan pendidikan. Dengan demikian, Kepala Sekolah menjadi sosok yang ideal untuk dapat dijadikan sebagai contoh atau panutan bagi para bawahannya sehingga dapat dipercaya, dihormati, 
dan diharapkan bisa mengambil keputusan yang terbaik untuk mencapai kepentingan sekolah. Mengefektifkan suatu organisasi ialah tujuan dari setiap kepemimpinan. Dari hal tersebut akan membuat seorang pempimpin menjadi pemimpin yang diinginkan oleh para bawahan (Rahayu, 2018).

Hal ini sesuai dengan pendapat Mulyasa (2013, h. 220) yang dikutip sebagai berikut:

"Tugas lembaga pendidikan bukanlah hal yang mudah, untuk dapat meningkatkan kualitas sumber daya manusia, strategi yang bagus saja belum cukup. Oleh karena itu, lembaga pendidikan diharapkan mampu mewujudkan pendidikan berkualitas yang sesuai dengan tuntutan zaman dengan berusaha untuk bisa menciptakan orang-orang yang mempunyai intelektual dan kreatifitas yang tinggi".

Sosok ideal seorang kepala sekolah dapat dijadikan sebagai panutan bagi para guru dan juga bawahannya sehingga dipercaya, dihormati dan mampu mengambil kebijakan-kebijakan yang terbaik demi kepentingan sekolah. Sebagai pemimpin, kepala sekolah dituntut untuk dapat melakukan transformasi kepemimpinan melalui pemberian bimbingan kepada para bawahan, motivasi, pembagian tugas sehingga tujuan sekolah dapat dicapai. Hal ini sesuai dengan perdapat Daryanto (2008, h. 80 ) dalam kutipan sebagai berikut, “Kepala sekolah juga merupakan bagian dari personel sekolah yang mepunyai tanggung jawab terhadap seluruh kegiatan yang ada di lembaga sekolah"

Kepemimpinan menjadi salah satu faktor yang utama dalam lembaga organisasi. Baik buruknya suatu organisasi tidak lepas dari peran seorang pemimpin. Kepemimpinan merupakan cara dari seorang pemimpin untuk dapat mempengaruhi para bawahan agar dapat bekerja sama dan produktif, sehingga tujuan organisasi dapat tercapai (Hasibuan, 2012). Hal yang sama juga diungkapkan oleh Zulkarnain (2013, h. 83) yang dikutip sebagai berikut "Kepemimpinan merupakan keahlian dari seseorang untuk dapat menggerakkan, mempengaruhi, dan juga mengarahkan tingkah laku orang lain agar dapat mencapai tujuan kelompok dalam situasi dan kondisi tertentu".

Dari beberapa pengertian tersebut bisa disimpulkan bahwa kepemimpinan adalah suatu perilaku yang dimiliki seorang pemimpin dalam mengarahkan individu atau sekelompok orang agar dapat bekerja menjalankan semua kegiatan sesuai dengan arahan yang diberikan.

Kepemimpinan transformasional menjadi salah satu gaya kepemimpinan kepala sekolah yang ditawarkan yaitu kepala sekolah yang selalu menghasilkan temuan baru, sehingga setiap tahunnya meningkatkan kualitas sekolah. Danim dan Suparno (2009, h. 62) mendefinisikan bahwa "Kepemimpinan transformasional kep ala sekolah ialah seorang individu yang sanggup membangun pergantian dalam lembaga organisasi sekolah dengan nilai-nilai yang ditentukan dengan mengembangkan semua komunitas sekolah lewat komunikasi yang terencana, 
sehingga para bawahan mampu bekerja lebih energik dan terfokus dalam pengajaran serta pembelajaran menjadi bersifat positif bagi tiap orang".

Seorang pemimpin disebut melaksanakan kaidah kepemimpinan transformasional bila dia sanggup mengganti sumber energi; baik manusia, instrumen, ataupun suasana dalam menggapai tujuan-tujuan reformasi sekolah. Kepemimpinan transformasional merupakan keahlian seorang pemimpin dalam bekerja dengan dan/atau lewat orang lain untuk mentransformasikan secara maksimal sumber energi organisasi dalam rangka menggapai tujuan yang bermakna dengan sasaran capaian yang sudah ditentukan. Sumber energi diartikan bisa berbentuk pimpinan, staf, bawahan, guru, sarana, dana, serta faktorfaktor keorganisasian (Danim, 2006).

Sebagaimana dikemukakan di atas bahwa kepemimpinan transformasional pada hakekatnya menekankan kedudukan pemimpin dalam memotivasi para bawahannya (guru dan staf) sehingga tergerak untuk bekerja melaksanakan tugasanya dan bertanggung jawab melebihi dari yang mereka harapkan.

Seorang pemimpin yang transformasional dapat mengubah dengan maksimal sumber daya kelompok dalam menggapai tujuan yang sudah ditentukan sebelumnya secara efektif dan efisien. Seperti yang dijelaskan dalam firman Allah swt. Q.S. An-Nahl (16) Ayat ke-125 sebagai berikut:

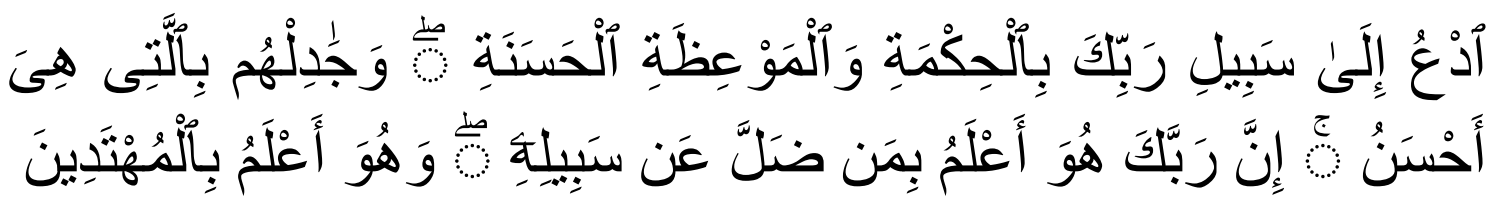

“(125) Serulah (manusia) kepada jalan Tuhan-mu dengan hikmah dan pelajaran yang baik dan bantahlah mereka dengan cara yang baik. Sesungguhnya Tuhanmu Dialah yang lebih mengetahui tentang siapa yang tersesat dari jalan-Nya dan Dialah yang lebih mengetahui orang-orang yang mendapat petunjuk" (Kementerian Agama Republik Indonesia, Al-Qur'an dan Terjemah, 2006).

Berdasarkan ayat tersebut tentang perintah taat kepada pemimpin lewat nasihat yang memiliki motivasi dan peringatan. Serulah (wahai Rasul) oleh-mu dan orang-orang yang mengikutimu kepada agama Tuhan-mu dan jalan-Nya yang lurus dengan metode bijaksana yang sudah Allah wahyukan kepadamu di dalam AlQur'an dan sunah. Dan bicaralah kepada manusia dengan tata cara yang sesuai dengan mereka, dan nasihati mereka dengan baik-baik yang akan mendorong mereka menyukai kebaikan dan menjauhkan mereka dari keburukan. Dan debatlah mereka dengan metode perdebatan yang terbaik, dengan halus dan lemah lembut. karena tidak terdapat kewajiban atas dirimu selain menyampaikan, Dan sungguh engkau telah menyampaikan, adapun anugrah bagi mereka terserah kepada Allah semata. la lebih tahu siapa saja yang sesat dari jalan-Nya dan la lebih tahu orangorang yang akan mendapatkan hidayah (Syakir, 2014). 
Jadi, dapat dipahami bahwa kepala sekolah sebagai pemimpin sanggup meningkatkan sekolah yang bermutu dalam menaggapi bermacam permasalahan yang dialami sekolah. Kepala sekolah apabila jadi pemimpin yang handal maka akan mampu melaksanakan aneka wujud transformasi dan mengadakan temuan baru, sehingga menjadikan sekolah berkualitas yang bermutu.

Adapun komponen kepemimpinan transformasional menurut Bass dan Riggio dalam Jabar dan Tukiman (2014), salah satunya adalah idealized influence, model kepemimpinan transformasional idealized influence, yakni "Transformational leaders behave in ways that allow them to serve as role models for their followers. The leaders are admired, respected, and trusted". Lebih lanjut dikatakan bahwa sikap pemimpin yang menciptakan rasa hormat (respect) dan rasa percaya diri (trust) dari orang-orang yang dipimpinnya. Idealized influence memiliki arti saling berbagi resiko lewat pertimbangan etis kebutuhan orang yang dipimpin di atas kebutuhan sendiri. Oleh karenanya, kepala sekolah adalah seorang individu yang bisa dijadikan sosok panutan bagi guru dan pegawainya, yang dipercaya, disegani serta sanggup mengambil kebijakan yang terbaik demi kemajuan sekolah.

Berdasarkan pengamatan peneliti di SMA Negeri 1 Barru Kabupaten Barru terkait implementasi kepemimpinan transformasional kepala sekolah belum sepenuhnya melakukan pengembangan dan pemberdayaan guru/staf karena jumlah guru yang banyak serta banyaknya tugas di luar sekolah, kepala sekolah belum maksimal dalam pemberian motivasi menyebabkan guru dan staf masih kurang bersinergi dalam menjalankan kewajibannya. Berdasarkan penjelasan tersebut, menarik untuk diteliti lebih lanjut beberapa hal sehubungan dengan implementasi kepemimpinan trasformasional kepala sekolah di SMA Negeri 1 Barru Kabupaten Barru.

\section{METODE PENELITIAN}

Jenis penelitian yng digunakan adalah penelitian kualitatif deskriptif yang dilakukan di SMA Negeri 1 Barru Kabupaten Barru. Adapun sumber data dalam penelitian ini terbagi atas sumber data primer dan sumber data sekunder. Sumber data primer yaitu data yang secara langsung didapat dari kepala sekolah dari kepala sekolah, guru,staf yang berjumlah keseluruhan 8 orang, sedangkan sumber data sekunder yaitu data yang dikumpulkan berupa profil sekolah, visi dan misi, struktur organisasi, serta keadaan guru/staf di SMA Negeri 1 Barru Kabupaten Barru. Pengumpulan data ewat observasi, wawancara dan dokumentasi. Data dianalisis dengan metode reduksi data, penyajian data, penarikan kesimpulan dan verifikasi. Pengujian keabsahan data melalui uji kredibilitas data (credibility), yaitu dengan teknik triangulasi (sumber, teknik, dan waktu) dan member check.

\section{HASIL PENELITIAN DAN PEMBAHASAN}

\section{Kepemimpinan Transformasional}

Kepemimpinan merupakan keahlian orang dengan memakai kekuasaannya dalam melaksanakan proses mempengaruhi, memotivasi, serta menunjang usaha 
yang memungkinkan orang lain membagikan donasi pada pencapaian tujuan lembaga (Wibowo, 2014). Dubrin (2009) mendefinisikan kepemimpinan, yakni sebagai keahlian buat menghasilkan rasa yakin dan dorongan diantara bawahan supaya tujuan organisasi bisa berhasil. Dengan kata lain, tugas pemimpin melindungi kerjasama bahawan yang bekerja di dalam oraganisasi. Kepemimpinan adalah keahlian pengaruhi sikap orang lain ataupun sekelompok orang untuk menggapai tujuan yang telah diputuskan. Organisasi akan baik bila pemimpin dalam melaksanakan kepemimpinannya juga baik dengan memberikan arahan, memotivasi dan menasehati, serta mampu menyelesaikan masalah-masalah yang terjadi bukan hanya sekedar memerintah saja, hal ini sesuai dengan kepemimpinan kepala sekolah di SMA Negeri 1 Barru yang telah diimplementasikan dengan semaksimal mungkin untuk dapat meningkatkan memotivasi bawahan dalam melakukan kerjasama tim pada organisasi sekolah.

Terdapat beberapa jenis kepemimpinan salah satunya yaitu kepemimpinan transformasional. Kepemimpinan transformasional inipun diimplementasikan di SMA Negeri 1 Barru.

Kepemimpinan transformasional dibentuk dari 2 kata adalah kepemimpinan (leadership) dan transformasional (transformational). Istilah transformasi berasal dari kata to transform yang bermakna mentrasformasikan atau mengganti sesuatu menjadi wujud lain yang berbeda, misalnya mentransformasikan visi jadi realita, ataupun mengganti suatu yang potensial jadi aktual (Indonesia, 2012). Kemudian, kepemimpinan transformasional ini awalnya dikemukakan oleh Burns yang dikutip dalam Komariah dan Triatna (2005, h. 77) bahwa "Kepemimpinan transformasional ialah proses yang dimana pemimpin dan para bawahannya berupaya dalam menggapai tingkatan moralitas dan motivasi yang lebih besar." Lebih diperjelas lagi bahwa kepemimpinan transformasional adalah suatu pendekatan yang berusaha untuk memotivasi bawahan atau pengikutnya untuk melakukan tanggung jawab meraka masing-masing dan untuk bekerja extra mile tanpa membuat bawahan atau pengikutnya merasa tertekan (Octaviana dan Silahi, 2016).

Berdasarkan beberapa pengertian tersebut maka implementasi kepemimpinan transformasional merupakan penerapan kepemimpinan kepala sekolah dengan memiliki sikap yang melakukan aksi memberdayakan para bawahan agar bekerja secara optimal melibatkan bawahan dalam penyusunan program pendidikan. Sesuai hasil penelitian di lapangan yang terjadi bahwa kepala sekolah telah melaksanakan pendekatan kepemimpinan transformasional ini dengan bukti bahwa telah terjadi pelibatan semua stakeholders yang ada seperti guru dan staf, maupun komite sekolah dalam perumusan visi dan misi pada jangka waktu tertentu, dengan dilakukannya pelibatan tersebut dapat memotivasi bawahan untuk tidak tertekan dan tanpa paksaan dalam pelaksanaan tugas dan tanggung jawab masing-masing karena menjadi keputusan bersama yang 
kemudian dengan bersama-sama atas himbauan dan arahan dari kepala sekolah visi dan misi sekolah dapat diaktualisasikan secara nyata. Hal ini membuktikan adanya perubahan atau transformasi yang dilakukan pemimpin untuk mencapai tingkat moralitas motivasi lebih tinggi.

Terdapat empat kompenen yang harus diperhatikan dan dipenuhi dalam mengimplementasikan kepemimpinan transformasional yaitu:

\section{Idealized Influence}

Implementasi kepemimpinan transformasional tidak terlepas dari komponen idealized influence yang mengaitkan para staf guru dan pegawai serta stakeholder yang lain dalam penataan visi, misi, tujuan, rencana strategis sekolah, dan program kerja tahunan sekolah serta kepemimpinan yang senantiasa mengutamakan kualitas secara terarah, sistematis, dan berkelanjutan. Komponen idealized influence dalam kepemimpinan transformasional adalah pemimpin yang mempunyai kepercayaan yang kokoh, komitmen besar, jelas, pekerja keras, konsisten, sanggup menujukkan ide-ide positif, serta sanggup menularkannya pada bawahannya, sanggup pengaruhi dan memunculkan emosi yang kokoh para pegawai terhadap target organisasi, memberi pengetahuan dan pemahaman akan misi, membangkitkan kebanggaan, serta meningkatkan keyakinan pada para bawahannya (Yuki, 2005). Demikian, maka ciri kepemimpinan transformasional kepala sekolah yang idealized influence adalah mampu memberi pengaruh ideal atau menjadi teladan bagi bawahananya.

Hasil penelitian di lapangan menunjukkan bahwa kepala SMA Negeri 1 Barru, terkait idealized influence yang dimiliki kepala sekolah, yakni pertama, pelibatan komite sekolah, guru serta staf yang diwakili oleh kepala tata usaha, dan staf yang lain bertugas dalam administrasi rapat dan persiapan rapat. Kedua, pemberian ide/pendapat maupun kritik dan saran, pembentukan tim perumusan visi misi, serta pemberian kesempatan untuk mengembangkan diri. Ketiga, langkah-langkah optimal peningkatan mutu, yaitu gaya kepemimpinan partisipatif, sosialisasi kebijakan/program sekolah melalui rapat dan upacara bendera, pembentukan SK Tim Penyusun Kurikulum, MGMP, pelatihan, workshop dan lainnya, pemberian tanggung jawab kepada guru sebagai wali kelas, kepala-kepala laboratorium, pembina ekstrakurikuler, serta pembina olimpiade.

Demikian maka kepala SMA Negeri 1 Barru dapat menjadi teladan dan memberikan pengaruh yang cukup ideal kepada bawahannya karena kepala sekolah dalam kepemimpinannya melakukan pelibatan dan pemberdayaan stakeholders sekolah, baik dari guru yang bersatus PNS maupun non-PNS, staf maupun komite sekolah dalam proses perumusan dan aktualisasi visi, misi dan program kerja, memberikan tugas dan tanggung jawab sesuai kompetensi yang dimiliki, serta perwujudan mutu yang terarah secara sistematik dan berkesinambungan. 


\section{Inspirational Motivation}

Salah satu ciri yang wajib dimiliki oleh seorang pemimpin adalah keahliannya untuk mendorong orang lain dalam menggapai tujuan ataupun visi dari lembaga. Pemimpin yang bermutu wajib bisa merubah sikap bawahannya menjadi seseorang yang merasa sanggup dan bermotivasi tinggi, sehingga tujuan organisasi dapat terlaksana (Septyan, Musadieq dan Mukzam, 2017).

Hasil penelitian di SMA Negeri 1 Barru menunjukkan bahwa kepala sekolah memotivasi dengan memberikan kesempatan kepada guru untuk mengembangkan ide/pendapat atau kreativitas, menumbuhkan keasadaran guru tentang pentingnya dalam menjalankan tugas yang diemban, kepala sekolah memberikan contoh ketika bersikap dan berperilaku sebagai top manager, memberikan pelatihan sebagai motivasi pengembangan diri secara fleksibel. Demikian, maka kepala sekolah mampu mengubah perilaku bawahannya dari yang tidak termotivasi menjadi seorang yang bermotivasi tinggi. Hal ini sesuai dengan pengertian dari komponen inspirational motivation yang merupakan sikap pemimpin transformasional yang menginspirasi, memotivasi dan merubah sikap para bawahan dalam melihat ancaman sebagai kesempatan untuk belajar dan berkarya. Hartanto (2009, h. 517) mengatakan bahwa "Pemimpin juga menghasilkan sistem organisasi yang dapat menginspirasi, memberikan tantangan kepada bawahan demi menggapai standar yang lebih besar, serta menghasilkan ajaran berani salah karena kesalahan adalah awal dari pengalaman belajar".

\section{Intellectual Stimulation}

Raihan (2011, h. 22) mengatakan bahwa "Intellectual stimulation adalah sikap kepemimpinan transformasional yang dapat menciptakan kesadaran para bawahan terhadap masalah diri/kelompok dan mempengaruhi pandangan masalah tersebut dari pendapat yang baru untuk menggapai target organisasi, meningkatkan pengetahuan, pemikiran, dan pemecahan masalah secara bersama".

Hasil penelitian di SMA Negeri 1 Barru menunjukkan bahwa intellectual stimulation yang dimiliki kepala sekolah adalah menghasilkan pengembangan budaya kerja yang aktif, etika kerja, mandiri, terbuka dalam penciptaan hubungan yang harmonis, dengan demikian akan dapat meningkatkan kesadaran individu dalam pemecahan masalah secara seksama serta kesadaran pentingnya mencapai tujuan, visi dan misi sekolah.

Kepemimpinan transformasional meliputi ikatan yang lebih intensif antara atasan dan bawahannya. Ikatan yang lebih intensif dengan bawahan dapat mempengaruhi bawahan untuk melaksanakan tugas dengan suka cita tanpa pksaan. Kepemimpinan transformasional mengungkapkan pimpinan yang memberikan perhatian individual dengan tugas yang diberikan sesuai dengan kemampuan bawahan, serta dapat melaksanakan stimulasi intelektual kepada bawahannya seperti cara menganalisis suatu kondisi dan cara agar bawahan aktif 
dalam mengembangkanya (Septyan, Musadieq dan Mukzam, 2017). Hal ini sesuai dengan hasil penelitian yang didapatkan di lapangan bahwa kepala sekolah memberikan tanggung jawab kepada setiap bawahannya sesuai dengan kemampuan yang dimiliki dengan demikian telah terjalin perhatian kepala sekolah terhadap individu bawahannya, tinggal bagaimana cara menstimulus untuk mengembangkan potensi yang telah ada.

\section{Individual Consideretion}

Komponen Individual consideretion dalam kepemimpinan transformasional ialah keahlian seorang pemimpin dalam menganggap setiap orang menjadi individu. Konsiderasi individual juga dapat dijalankan dengan membela kebutuhan dan ide anggota di hadapan orang lain, selama hal itu masih searah dengan visi dan misi organisasi (Hartanto, 2009).

Gaya kepemimpinan transformasional seorang pemimpin peka terhadap kerukunan dan perbedaan yang ada pada setiap orang. Jadi pemimpin ini akan mengarahkan, mengembangkan dan menaungi bawahannya dengan metode yang berbeda terhadap setiap orang. Hal ini dikarenakan pemimpin mengerti bahwa setiap orang itu unik dan memerlukan pendekatan yang beragam. Olehnya itu, ada rasa saling menghargai antara atasan dan bawahannya (Octaviana dan Silahi, 2016).

Berdasarkan hasil penelitian menunjukkan bahwa individual consideretion di SMA Negeri 1 Barru dalam kepemimpinan transformasional kepala sekolah yaitu cepat dan peduli dengan kebutuhan guru maupun staf, baik kebutuhan fisiologis, kesejahteraan, serta kebutuhan akan rasa aman. Hal ini menunjukkan kepala sekolah yang transformasional karena dapat memahami dan peka terhadap kebutuhan setiap individu bawahannya.

Selain itu, kepala SMA Negeri 1 Barru juga melakukan pengembangan profesionalisme guru dan staf melalui supervisi secara langsung dan tidak langsung, melanjutkan pendidikan magister, MGMP (Musyawarah Guru Mata Pelajaran), workshop pendidikan, dan training lainnya, supervisi dilakukan internal sekolah dan eksternal sekolah, yang terdiri dari supervisi administrasi dan supervisi pembelajaran di kelas. Hal ini dilakukan tidak lain sebagai bentuk perhatian dan tanggung jawab dari seorang pemimpin sekolah untuk memenuhi kebutuhan pendidik dan tenaga kependidikan SMA Negeri 1 Barru.

Berdasarkan hasil peneltian di lapangan, peneliti juga menemukan bahwa kepla sekolah SMA Negeri 1 Barru dalam kepemimpinannya pada komponen individual consideretion adalah kepala sekolah menjaga perasaan guru dan staf dengan memberikan nasehat atau teguran secara halus, ramah, tidak menegur di depan warga sekolah lainnya, namun melakukan pemanggilan secara pribadi serta tidak berkesan menggurui. Hal ini menunjukkan implementasi kepemimpinan transfomasional kepla SMA Negeri 1 Barru. 


\section{PENUTUP/SIMPULAN}

Implementasi idealized influence kepala sekolah di SMA Negeri 1 Barru Kabupaten Barru yaitu pertama, pelibatan semua warga sekolah dalam penyusunan tujuan sekolah, namun bagi staf hanya diwakili oleh kepala tata usaha, dan staf yang lain bertugas dalam administrasi rapat dan persiapan rapat. Kedua, pemberian ide/pendapat dari warga sekolah, pembentukan tim perumusan visi misi, serta pemberian kesempatan untuk mengembangkan diri bagi guru, walaupun belum secara optimal karena jumlah guru banyak. Ketiga, langkah optimal peningkatan mutu, yaitu gaya kepemimpinan partisipatif, sosialisasi kebijakan serta pembentukan pelaksana kegiatan.

Hendaknya visi, misi dan tujuan sekolah, setiap tahunnya dilaksanakan dievaluasi agar dapat disesuaikan dengan tantangan dan peluang sekolah di era 4.0. SMA Negeri 1 Barru sebagai sekolah yang besar harus meningkatkan komunikasi serta kerja sama dengan semua stakeholder yang ada, guru dan staf, juga orang tua siswa, untuk mensosialisasikan kebijakan di sekolah. Hendaknya kepala sekolah sebagai top manager dapat merangkul semua tenaga pendidik di sekolah yang jumlah guru sangat banyak, mampu melakukan pembagian tugas dan tanggung jawab secara adil, serta perlakukan yang sama terhadap tenaga pendidik dan kependidikan PNS maupun non-PNS.

\section{DAFTAR PUSTAKA}

Danim, S. (2006). Visi Baru Manajemen Sekolah, dan unit Birokrasi ke Lembaga Akademik. Jakarta: Bumi Aksara.

Danim, S. dan Suparno. (2009) Manajemen dan Kepemimpinan Transformasional kepalasekolahan. Jakarta: Rineka Cipta.

Daryanto. (2008). Administrasi Pendidikan. Jakarta: Rineka Cipta.

Hartanto, F. M. (2009). Paradigma Baru Manajemen Indonesia: Menciptakan Nilai dengan Bertumpu pada Kebajikan dan Potensi Insani. Bandung: PT Mizan Pustaka.

Hasibuan, M. (2012). Manajemen Sumber Daya Manusia. Jakarta: Bumi Aksara.

Indonesia, T. D. A. P. U. P. (2012). Manajemen Pendidikan. Bandung: Alfabeta.

J. Dubrin, A. (2009). The Complete Ideal's Guides: Leadership. Jakarta: Prenada.

Jabar, C. S. A. dan Tukiman. (2014). Implementasi Kepemimpinan Transformasional Kepala Sekolah Dalam Meningkatkan Mutu Sekolah Di SD Kanisius Sengkan Kabupaten Sleman, Jurnal Akuntabilitas Manajemen Pendidikan, 2(1), pp. 121-134. https://doi.org/10.21831/amp.v2i1.2414

Komariah, A. dan Triatna, C. (2005). Visionary Leadership Menuju Sekolah Efektif. Jakarta: Bumi Aksara.

Mulyasa. (2013). Pengembangan dan Implementasi Pemikiran Kurikulum. Bandung: Rosdakarya.

Octaviana, M. dan Silahi, D. K. (2016). Kepemimpinan impinan Transformasional Kepala Sekolah, A Journal of Language, Literature, Culture, and Education, 
12(1). http://dx.doi.org/10.19166/pji.v12i1.376

Rahayu, Renita Silvia. (2018). Implementasi Kepemimpinan Transformasional Kepala Sekolah Dasar Negeri, Jurnal Manajemen dan Supervisi Pendidikan, 2(3), $\mathrm{pp}$. 192-201 http://journal2.um.ac.id/index.php/jmsp/article/view/4653.

Raihan. (2011). Kepemimpinan Sekolah Transformatif. Yogyakarta: PT. LkiS Printing Cemerlang.

Kementerian Agama Republik Indonesia. (2006). Al-Hikmah, Al-Qur'an dan Terjemahannya. Jakarta: Bumi Restu.

Septyan, Faris Bayu, Musadieq, Mochammad Al dan Mukzam, Muhammad Djudi. (2017). 'Pengaruh Gaya Kepemimpinan Transformasional Terhadap Motivasi Kinerja (Studi Pada Karyawan CV. Jade Indopratama Malang)', Administrasi Bisnis, 53(1), pp. 81-88. http://administrasibisnis.studentjournal.ub.ac.id/index.php/jab/article/view $/ 2185$

Syakir, S. A. (2014). Mukhtasar Tafsir Ibnu Katsir. Jakarta: Darus Sunnah Press.

Wibowo. (2014). Perilaku dalam Organisasi. Jakarta: Rajawali Pers.

Yukl, G. (2005). Kepemimpinan Dalam Organisasi: Leadership in Organization. Edited by B. Suprianto. Jakarta: Indeks.

Zulkarnain. (2013). Dinamika Kelompok; Latihan Kepemimpinan Pendidikan. Jakarta: Bumi Aksara. 